\title{
Protector Effect of Curcumin against the Nasal Mucosa after Cigarettes Smoke Exposure
}

\author{
Abdul Qadar Punagi ${ }^{1}$, Sutji Pratiwi Rahardjo ${ }^{2,}$ Ervina Mariani $^{3}$, Upik Miskad $^{4}$ \\ ${ }^{1}$ Supervisor \& Chief of Department Rhinology Division Department of Ear Nose Throat, Medical Faculty, Hasannuddin University, \\ Makassar, Indonesia \\ ${ }^{2}$ Supervisor, Department of Ear Nose Throat, Medical Faculty, Hasanuddin University, Makassar, Indonesia \\ ${ }^{3}$ Senior resident, Department of Ear Nose Throat, Medical Faculty, Hasanuddin University, Makassar, Indonesia \\ ${ }^{4}$ Supervisor, Department of Pathology Anatomy, Medical Faculty, Hasanuddin University, Makassar, Indonesia
}

\begin{abstract}
Introduction: The level of cigarette consumption in Indonesia is very high and causes the magnitude of the danger that may result in respiratory and cancer risk. This study aims to determine the effectiveness of curcumin in improving nasal mucosa of Wistar mice as a result of exposure to cigarette smoke. Materials and methods: The study was conducted from March to August 2015. The study was conducted in animal experiments laboratory and research unit of the Medical Faculty of Hasanuddin University. The study sample of 15 Wistar mice were divided into three groups: the provision of cigarette smoke, the group with the provision of smoke and curcumin 200mg, the group with the provision of smoke and curcumin 400mg. Results: Results of the study group I showed that the changes in the nasal mucosa of Wistar mice in the form of inflammation, erosion, epithelial disarrangement and epithelial metaplasia. Group II and group III showed a significant difference in the degree of inflammation in group $(p<0.01)$. There are significant differences in the incidence of erosion and epithelial disarrangement according to group ( $p<0.05$ ). Disarrangement of epithelial incidence was significantly higher in the control group compared to the group of curcumin. There are significant differences in the incidence of epithelial metaplasia according to group ( $p<0.05)$. Conclusion: The exposure to cigarette smoke causes changes in the nasal mucosa of Wistar mice, administration of curcumin as protection can reduce inflammation, epithelial erosion, epithelial disarrangement and epithelial metaplasia.
\end{abstract}

Keywords: Cigarette smoke, Curcumin, Nasal mucosa

\section{Introduction}

Cigarette smoke is a cause of morbidity and premature mortality of the most important in the world's population could have been prevented. Early mortality is estimated at 4.8 million people every year around the world as reported in 2000 with 2.4 million of them in developing countries and the rest happens in the developed countries. ${ }^{[1,2]}$ This figure increased to 5.4 million deaths annually in 2006. World health organization (WHO) estimates that the figure is likely to continue rising and will reach 10 million of deaths per year by $2030 .{ }^{[3]}$ From the results of research data shows that the behavior of smoking may reduce the life expectancy of up to 8.8 million years. ${ }^{[4]}$ In Indonesia, according to the agency reports of demographic data from the University of Indonesia, the number of smokers reaches 57 million of people. ${ }^{[5]}$ It is estimated that more than half of them will die from illnesses caused in the long term, with the average of 427.498 deaths per year. ${ }^{[5]}$

Based on WHO data, most types of cigarettes consumed in Indonesia are clove cigarettes. It is containing approximately a quarter section and the remainder added special flavor that characterizes each of the cigarette brand. The results of the Global Youth Tobacco Survey (2000) reported that approximately there is $88 \%$ of smokers in Indonesia are more like the type of cigarette and $12 \%$ which types of white cigarettes. The levels of tar and nicotine in cigarettes are much higher than that of white cigarettes (cigarettes without clove). In general, clove cigarettes sold in Indonesia contain from 1.9 to $2.76 \mathrm{mg}$ nicotine and $34-65 \mathrm{mg}$ of tar per cigarette, while the white cigarettes containing from 0.05 to 1.4 and $0.5 \mathrm{mg}$ nicotine $-2.4 \mathrm{mg}$ tar per cigarette. ${ }^{[6]}$ Cigarette smoke can potentially produce more than the white smoke. ${ }^{[7]}$

In recent years, the dangers of cigarette smoke is not only focused on people who have the habit of smoking (active smoker), but against people who do not smoke (passive smokers) and inhale cigarette smoke produced by active smokers. Passive smokers have the same chance of getting a disease and even higher than current smokers. ${ }^{[8,9]}$ This is caused by passive smokers that inhale the smoke from the side stream coming out of the tip of a burning cigarette and the part of the main smoke. ${ }^{[10]}$ Side stream smoke more than the mainstream smoke and contain more hazardous materials because it is without filtration or filter. ${ }^{[7,11]}$ Respiratory disorders or the changes in the airway epithelium from cigarette smoke can be: a) the loss of cilia, b) mucus gland hypertrophy and increased the number of goblet cells, c) a decrease in bronchial epithelial layer, and d) a decrease in the content of glutathione peroxides (GSH) lung tissue. ${ }^{[12,13]}$

Indonesia has a wealth of exceptional biodiversity, which is about 40.000 species of plants, of these about 13.000 which are used in traditional medicine. Based on this potential for traditional medicinal products can be extended developed. ${ }^{[14]}$ One type of plant that is extended used as a traditional medicine are turmeric (Curcuma).

According to Tonnessen, curcumin contained in turmeric as one of the isolated compounds has many function, such as 


\section{International Journal of Science and Research (IJSR) \\ ISSN (Online): 2319-7064}

Index Copernicus Value (2013): 6.14 | Impact Factor (2014): 5.611

anti-oxidants, anti-hepatotoxic, anti-inflammatory, and antiarthritic. ${ }^{[15]}$ Curcumin is also reported to induce antiinflammatory properties in mice induced karagen. ${ }^{[16]}$ Curcumin as an anti-inflammatory mechanism by inhibiting the production of prostaglandin mediated through the inhibition of the enzyme activity of cyclooxygenase. ${ }^{[17]}$

Seeing so much cigarette consumption in Indonesia, the magnitude of the danger that may result in respiratory and cancer risk and the lack of study on the dangers of cigarette smoke to the upper respiratory tract, it is necessary to conduct further research on the impact/ influence of smoking on histological features of nasal mucosa with wistar mice as an experimental animals.

\section{Materials and Methods}

This research is an experimental (true experimental design) using the control group and the group treated with simple randomization. Animal experiments are the Wistar mice were randomly divided into 3 groups: a control group and two treatment groups with an exposure to the cigarette smoke.

The study was conducted in the laboratory of animal experiments and research unit of the Medical Faculty of Hasanuddin University. The protocol was conducted in accordance with principles of good clinical practice, and was approved by the human studies committees applicable to each study site. The study was conducted from May 2015 to August 2015. This study used 15 subjects of Wistar mice weighing 150-200 grams. Inclusion criteria, among others, a healthy condition, there is no anatomical abnormalities, and normal Wistar mice weight $150-200$ grams at age 3-4 months, whereas exclusion criteria include Wistar mice had diarrhea, it is with a pouch of rice cramped, experiencing rhinitis, as well as the Wistar mice that died during the study.

Determination of the sample are in accordance with the provisions of the WHO which each of samples at least 5 mice for each groups. This study used 15 Wistar mice were divided into 3 groups with simple randomization is one control group and two treatment groups; therefore, one group consists of $5 \mathrm{Wistar}$ mice.

\section{Results}

The first group is a positive control. Mice in this group were given only smoke just dive 28 days later then examine by biopsy and histopathology. The second group is the treatment groups. Mice in this group were given a smoke and $200 \mathrm{mg}$ of curcumin for 28 days after the biopsy and histopathology. While the third group was a treated group and the mice in this group were given a smoke and $400 \mathrm{mg}$ of curcumin for 28 days after the biopsy and histopathology. Data were analyzed using statistical tests Kruskal-Wallis test. The results obtained are presented in tables. The data is refineries with a computerized system by using SPSS 20 . Assessment of hypothesis testing results is declared significant if $\mathrm{p}<0.05$.

The general characteristics of the study sample will be presented in a systematic way that can be seen in Table 1.
Characteristics of the study sample consisted of inflammatory/ neutrophils, erosion, disarrangement epithelium, epithelial metaplasia after exposure to cigarette smoke and the provision of curcumin.

Table 1: Sample characteristics based on inflammation/ neutrophils, erosion, epithelium disarrangement, epithelial metaplasia after cigarette smoke exposure

\begin{tabular}{|c|c|c|}
\hline \multirow{2}{*}{ Variable } & \multicolumn{2}{|c|}{ Sample $(n=15)$} \\
\hline & $N$ & $\%$ \\
\hline \multicolumn{3}{|c|}{ Inflammation / neutrophils } \\
\hline a. Mild & 8 & 53.3 \\
\hline b. Moderate & 3 & 20.0 \\
\hline c. Severe & 4 & 26.7 \\
\hline \multicolumn{3}{|l|}{ Erosion } \\
\hline a. Negative & 8 & 53.3 \\
\hline b. Positive & 7 & 46.7 \\
\hline \multicolumn{3}{|c|}{ Epithelium disarrangement } \\
\hline a. Negative & 8 & 53.3 \\
\hline b. Positive & 7 & 46.7 \\
\hline \multicolumn{3}{|l|}{ Epithelial Metaplasia } \\
\hline a. Negative & 11 & 73.3 \\
\hline b. Positive & 4 & 26.7 \\
\hline
\end{tabular}

Table 1 shows the frequency and percentage of samples by inflammatory/ neutrophils, erosion, epithelium disarrangement, epithelial metaplasia. The obtained by histopathology inflammation/ neutrophil most in mild inflammation as much as 8 mice, furthermore inflammatory weigh as much as four mice, then inflammation were as many as 3 mice. Based on the obtained erosion as much as 8 mice are not eroded and 7 mice were eroded. Based on the epithelial disarrangement, there are 8 mice that did not undergo the epithelial disarrangement and 7 mice were experiencing. Based on the occurrence of epithelial metaplasia obtained 11 mice that did not undergo metaplasia and 4 mice contained epithelial metaplasia.

Table 2: The comparative effectiveness of the three kinds of group

\begin{tabular}{|c|c|c|c|c|}
\hline Variable & Group & $\mathrm{n}$ & Mean Rank & $\mathrm{p}$ \\
\hline Inflammation & Curcumin 400 & 5 & 5.6 & \multirow{3}{*}{0.005} \\
\cline { 2 - 4 } & Curcumin 200 & 5 & 5.6 & \\
\cline { 2 - 4 } & Control & 5 & 12.8 & \\
\hline \multirow{3}{*}{ Erosion } & Curcumin 400 & 5 & 6.0 & \multirow{3}{*}{0.018} \\
\cline { 2 - 4 } & Curcumin 200 & 5 & 6.0 & \\
\cline { 2 - 4 } & Control & 5 & 12.0 & \\
\hline Epithelial & Curcumin 400 & 5 & 6.0 & \multirow{3}{*}{0.018} \\
\cline { 2 - 4 } Disarrangement & Curcumin 200 & 5 & 6.0 & \\
\cline { 2 - 4 } & Control & 5 & 12.0 & \\
\hline Epithelial & Curcumin 400 & 5 & 6.0 & \multirow{3}{*}{0.006} \\
\cline { 2 - 4 } Metaplasia & Curcumin 200 & 5 & 6.0 & \\
\cline { 2 - 4 } & Control & 5 & 12.0 & \\
\hline
\end{tabular}

Kruskal-Wallis test

There are significant differences in the degree of inflammation in group $(\mathrm{p}<0.01)$. Severe inflammation was significantly higher in the control group compared to the group of curcumin. Moreover, the significant differences is also occurs in the incidence of erosion according to group ( $\mathrm{p}$ $<0.05)$. The erosion significantly higher incidence in the control group compared to the group of curcumin.

\section{Volume 4 Issue 11, November 2015}




\section{International Journal of Science and Research (IJSR) \\ ISSN (Online): 2319-7064}

Index Copernicus Value (2013): 6.14 | Impact Factor (2014): 5.611

The significant differences is also happens in the incidence of epithelial disarrangement according to group ( $p<0.05$ ). The disarrangement of epithelial incidence was significantly higher in the control group compared to the group of curcumin. There are significant differences in the incidence of epithelial metaplasia according to group $(p<0.01)$. The epithelial Metaplasia incidence was significantly higher in the control group compared to the group of curcumin. The entire variables are higher in the control group than in the curcumin group.

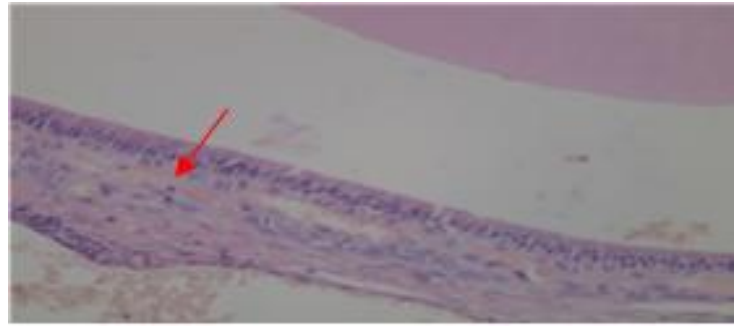

Figure 3: Mild inflammation, $<25 \%$ cell infiltration - an inflammation of the connective tissue cell sub-epithelial

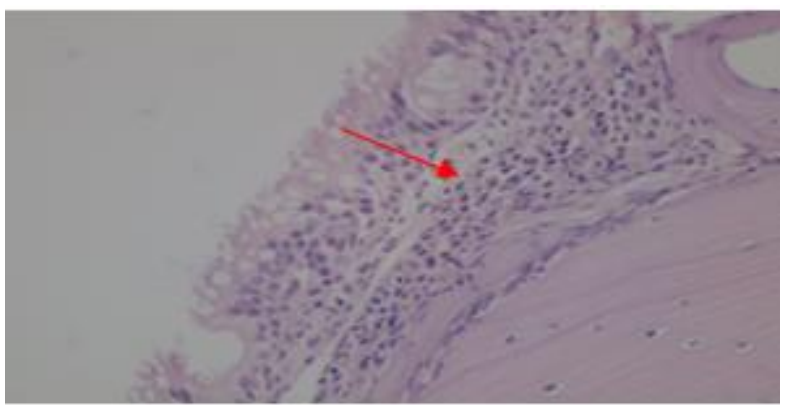

Figure 4: Moderate inflammation, 25\% - 50\% of cell infiltration - an inflammation of the connective tissue cell sub-epithelial

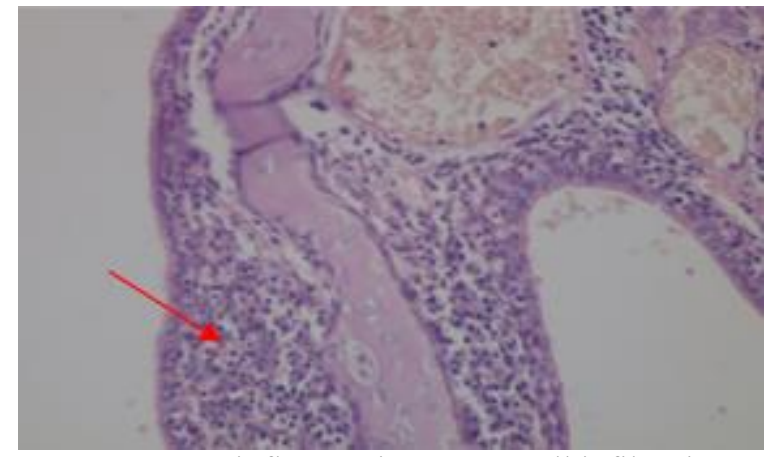

Figure 5: Severe inflammation $>50 \%$ cell infiltration - an inflammation of the connective tissue cell sub-epithelial

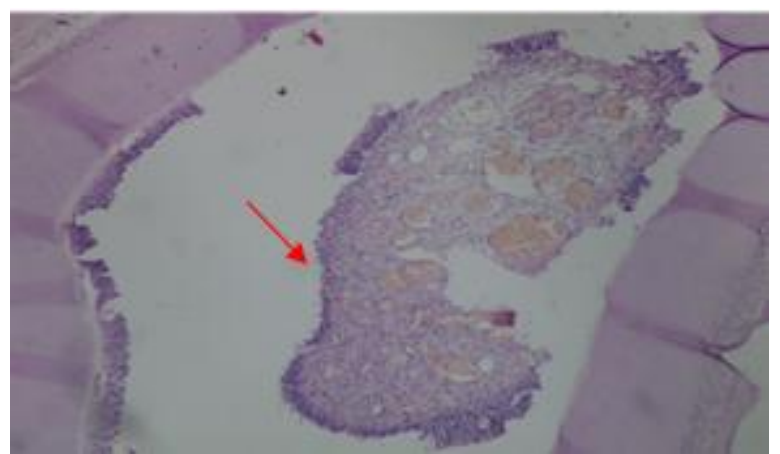

Figure 6: Erosion of the epithelium in the nasal mucosa of Wistar mice

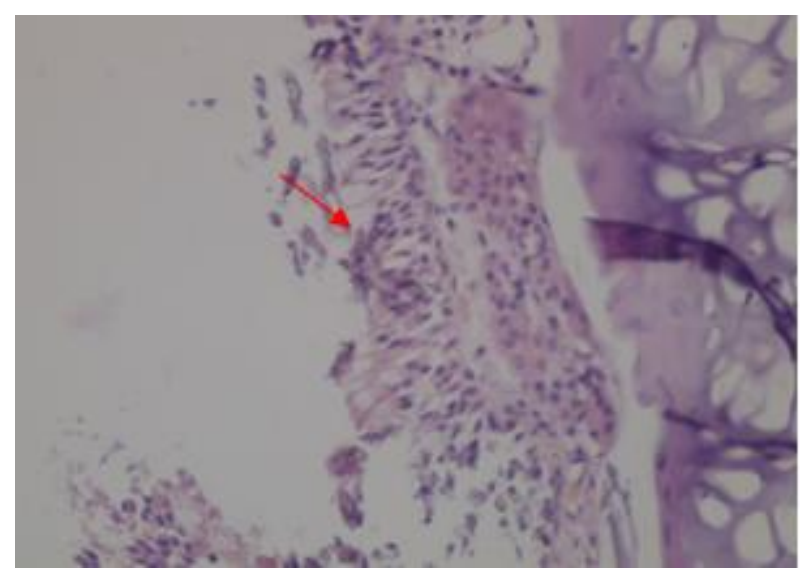

Figure 7: Disarrangement of the nasal mucosa epithelium of Wistar mice

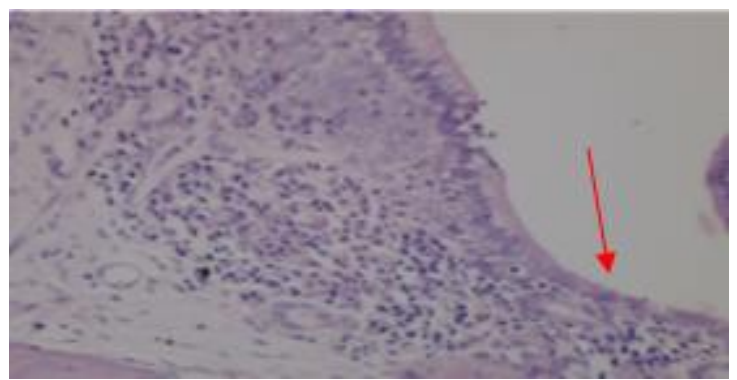

Figure 8: Metaplasia epithelium in the nasal mucosa of Wistar mice

\section{Discussion}

In table 1 shows the group I a control group who exposure to cigarette smoke, as many as four Wistar mice inflamed weight, whereas one mice inflammatory medium, total of 5 mice eroding the epithelium and the epithelial disarrangement, and 4 mice that undergo metaplasia epithelium and 1 mice which do not undergo epithelial metaplasia. Group II is a treatment group who are exposure to cigarette smoke and curcumin $200 \mathrm{mg}$, as many as four Wistar mice slight inflammation, whereas one mice is an inflammation, as much as 4 mice eroded epithelium, 1 mice did not experience erosion and as much as 4 mice undergoing epithelial disarrangement, 1 mice did not undergo epithelial disarrangement and 5 mice do not undergo epithelial metaplasia. Group III is the treatment group who exposure to cigarette smoke and curcumin $400 \mathrm{mg}$, as many as four Wistar mice slight inflammation, whereas one mice is an inflammation, as much as 4 mice eroded epithelium, 1 mice did not experience erosion and as much as 4 mice undergoing epithelial disarrangement, 1 mice did not undergo epithelial disarrangement and 5 mice do not undergo epithelial metaplasia.

In Table 1 shows that the three groups of samples found there are 15 mice inflamed inflammation either mild, moderate or severe it is characterized by the infiltration of cells - lymphocytes inflammatory cells, polymorph nuclear leukocytes, eusinofil in sub-epithelial. 8 mice eroded surface of the epithelial lining of the nasal mucosa, 8 mice undergo epithelial disarrangement, and 4 mice that undergo epithelial metaplasia. The erosion, epithelial metaplasia epithelial disarrangement and this indicates a more severe inflammatory process. In this study, in addition to the above 


\section{International Journal of Science and Research (IJSR) \\ ISSN (Online): 2319-7064}

Index Copernicus Value (2013): 6.14 | Impact Factor (2014): 5.611

also found congestion and dilated vascular containing erythrocytes and the presence vacuolization and polarity of the core is not regular, it is consistent with studies by Zeid and Muller that exposure to cigarette smoke can cause inflammatory and neoplastic changes in the respiratory tract. ${ }^{[18]}$ Majeed et al. suggest that cigarette smoke can cause inflammation, epithelial squamous metaplasia, and the symptoms of the erosion of the airways. ${ }^{[19]}$ Czekaj et al. also conducted a research on the effects of cigarette smoke on pregnant mice, they found a squamous metaplasia, cystic degeneration and inflammatory granuloma (specific epithelial cells with inflammatory cells). ${ }^{[20]}$ Shields and Jeffery reported a hypertrophic, hyperplasic and sometimes keratinized metaplasia in pseudo stratified tracheal epithelium caused by exposure to cigarette smoke. ${ }^{[21]}$ Mori et al. reported a mild disarrangement of epithelial and vascular congestion caused by exposure to cigarette smoke. ${ }^{[22]}$

Table 2 shows there is a significant difference in the degree of inflammation in group $(p<0.01)$. Severe inflammation was significantly higher in the control group compared to the group of curcumin. There are significant differences in the incidence of erosion according to group $(p<0.05)$. Erosion significantly higher incidence in the control group compared to the group of curcumin. There are significant differences in the incidence of epithelial disarrangement according to group $(\mathrm{p}<0.05)$. Disarrangement of epithelial incidence was significantly higher in the control group compared to the group of curcumin. There are significant differences in the incidence of epithelial Metaplasia according to group $(\mathrm{p}<0.01)$. Epithelial Metaplasia incidence was significantly higher in the control group compared to the group of curcumin. This is consistent with research by Tyndale et al. which proved that curcumin has anti-oxidant effects, analgesic, anti-inflammatory, inhibiting the cancer cells are abnormal and anti Alzheimer's. ${ }^{[23]}$ Curcumin as one of the active ingredients of turmeric can inhibit the formation of prostaglandins and suppress activity of the enzyme cyclooxygenase. ${ }^{[17]}$

There are differences in the effectiveness between the groups of curcumin $200 \mathrm{mg}$ and $400 \mathrm{mg}$ against inflammation, erosion, epithelial disarrangement and epithelial metaplasia (all $p>0.05$ ) which is in line with the research by Erlina states that the effects of turmeric extract (curcumin) with various doses showed anti-inflammatory effects as well as a more powerful inflammatory effects at a dose of $1000 \mathrm{mg}{ }^{[24]}$

There are also significant differences in the degree of inflammation in group $(\mathrm{p}<0.01)$. Severe inflammation was significantly higher in the control group compared to a group of $200 \mathrm{mg}$ and $400 \mathrm{mg}$ of curcumin group. There are significant differences in the incidence of erosion according to group ( $\mathrm{p}<0.05)$. Erosion significantly higher incidence in the control group compared to a group of 200 curcumin and curcumin $400 \mathrm{mg}$ group. There are significant differences in the incidence of epithelial disarrangement according to group ( $\mathrm{p}<0.05$ ). Disarrangement of epithelial incidence was significantly higher in the control group compared to a group of $200 \mathrm{mg}$ and $400 \mathrm{mg}$ of curcumin group. There are significant differences in the incidence of epithelial metaplasia according to group $(\mathrm{p}<0.05)$. Genesis Metaplasia epithelial significantly higher in the control group compared to the group of curcumin $200 \mathrm{mg}$ or a group of curcumin 400 $\mathrm{mg}$, this is consistent with the study on curcumin as an antiinflammatory by inhibiting the COX enzyme that overproduction of prostanoid can be prevented and will reduce the effects of anti-inflammatory or reduce cancer cell proliferation and accelerate the process of apoptosis. Curcumin have antioxidant activity, anti-inflammatory, antiinfective anticancer. Curcumin also been reported to inhibit cell proliferation in vivo of lung cancer and colon cancer cells in vitro, when administered during the initiation phase and metastasis. ${ }^{[17]}$

\section{Conclusion}

From the results, it can be concluded that exposure to cigarette smoke can cause inflammation, erosion, epithelial disarrangement and epithelial metaplasia. Besides giving the curcumin as protection, it also can reduce the inflammation, erosion, epithelial disarrangement and epithelial metaplasia. There is no significant difference between the dose of curcumin $200 \mathrm{mg}$ or $400 \mathrm{mg}$ of curcumin in reducing the incidence of inflammation, epithelial erosion disarrangement and epithelial metaplasia.

\section{Future Scope}

For further study, we should use more samples and a long duration in the observation to make a comparison between the results of each group of study for the better.

\section{References}

[1] Burns, D.M. Nicotine Addiction. In D.L. Kasper, E. Braunwalds, A.S. Fauci, S.L. Hauser, D.L. Longo, J.L. Jameson (Eds), Harrison's Principles of Internal Medicine, $16^{\text {th }}$ Edition. New York: McGraw-Hill. 2005; 2573-2577

[2] Mc Phee, S.J., Pignone, M. Disease Prevention and Health Promotion. In S.J. Mc Phee, M.A, Papadakis, \& L.M. Tierney Jr (Eds), Current Medical Diagnosis and Treatment, $47^{\text {th }}$ Edition, New York : McGraw-Hill. 2007; 1-16

[3] Uraih, Linda., C. Maronpot, R R. Normal histology of the Nasal Cavity and Application of Special Technique. Environmental health perspectives. New York. 1980; (85): 187-208

[4] Streppel, M.T., Boushuizen, H.C., Ocke, M.C., Kok, F.J., Kromhout D. Mortality and life expectancy in relation to long term cigarette, cigar and pipe smoking: the Zutphen Study. Tobacco Control. 2007; (16): 2

[5] Barber, S., Adioetomo, S.M., Ahsan, A., Setyonaluri, D. Tobacco economics in Indonesia. Research Report. Jakarta: the Demographic Institute at the Faculty of Economics, University of Indonesia. 2008

[6] Widodo Eddy., Priosoeryanto Pontjo Bambang., Estuningsih Sri., Rat Dewi. Effect of Clove Cigarette Exposure on White Mice: Special Emphasis on the Histopathology of Respiratory Tract. Medical Journal Indonesia. 2007; (16): 4

\section{Volume 4 Issue 11, November 2015}




\section{International Journal of Science and Research (IJSR) \\ ISSN (Online): 2319-7064}

Index Copernicus Value (2013): 6.14 | Impact Factor (2014): 5.611

[7] Susanna Dewi., Hartono Budi., Fauzan Hendra. Determination of Nicotine Levels in Cigarettes Smoke. Makara Health. 2003; (7): 2.

[8] Aggarwal BB., Kumar A., Aggarwal MS., Shishodia S. Curcumin Derived from Turmeric (Curcuma Longa): a spice for all season. CRC Press LLC. 2005

[9] Ballenger JJ. Anatomy Diseases Surgery Nose and Ear Nose Throat Head and Neck, Issue 13. Binarupa Aksara. 1994; (1): 318-27

[10]Brinton LA., Blot WJ., Becker JA., Winn DM., Browder JP., Farmer JC Jr. A case- control study of cancers of the nasal cavity and paranasal sinuses. Am I Epidemiol. 1984; 119: 896 - 906

[11]Dye, A., Janice. Adler., Kenneth., B. Effects of Cigarette Smoke on Epithelial Cells of the Respiratory Tract. Thorax. 1994; 49: 825 - 834

[12] Hanslavina Arkeman. Acute affects Smoke Cigarettes against Goblet Cell Hyperplasia at respiratory tract Swiss Webster mice strains. Indonesian Scientific Resource. Indonesia University. 2003

[13] Hukkanen, J., Jacob III, P., Benowitz, N.L. Metabolism and Disposition Kinetics of Nicotine. The American Society for Pharmacology and Experimental Therapeutics. 2005; (57): 1

[14] Sapoetra GK. Efficacious Drug Cultivation. Rineka Cipta: Jakarta. 1992

[15]Khan, M, Azim. Effect of Phenol, Benzalkonium Chloride, Oxymetazoline, Tobacco and Formalin on Nasal Mucosa of Albino Mice. J, Anat, Soc. India. 2006; 55(1) $60-66$

[16] Sudjarwo SA. Curcumin as an Anti-Inflammatory Potential in Mice induced by Karagen. Med. Ked. Vet., Jakarta. 2003

[17] Sudjarwo SA. The Signal Transduction of Curcumin as Anti Inflammatory Agent in Cultured Fibroblasts. YARSI Medical Journal. 2004; 12

[18]Zeid NA., Muller HK. Tobacco smoke induced lung granulomas and tumors' association with pulmonary Langerhans cells. Pathology. 1995; 27: 247 - 254

[19] Majeed M., V. Badmaev., U. Shirakumar Rajedran R. Curcuminoids Antioxidant Phytonutriens. Pis Cathway: 3-24., NJ: Nutrition Science Publisher Inc. 1995

[20] Czekaj P., Palasz A., Lebda - Wyborny T., NowaczykDura G., Karczewska W., Florek E., Kaminsky M. Morphological changes in lungs, placenta, liver and kidneys of pregnant mice exposed to cigarette smoke. International achieves of Occupational and Environmental Health. 2002; (75): S27-S35

[21] Shields PA., Jeffery PK. The Combined Effect of Vitamin - A Deficiency and Cigarette Smoke on Mice Tracheal Epithelium. British Journal of Experimental Pathology. 1987; 68: $705-717$.

[22] Mori Y., Limura K., Furukawa F., Nishikawa A., Takahashi M., Konishi Y. Effect of Cigarette Smoke on the Mutagenic Activation of Various Carcinogens in Hamsters. Mutation Research. 1995; 346: 1-8

[23] Tyndale, R.F. \& Sellers, E. Variable CYP2A6-Mediated Nicotine Metabolism Alters Smoking Behavior and Risk. The American Society for Pharmacology and Experimental Therapeutics. 2005; (29): 4.

[24] Erlina Rustam., Atmasari Indah., Yanwirasti. Antiinflammatory Effects of Ethanol Extracts of Turmeric (Curcuma Domestica Val.) in male Wistar Mice strain.
Journal of Pharmaceutical Science and Technology. Indonesia. 2007; 12: (2) 112-115 